\title{
Characterization and optimization of alkali-treated yushania alpina bamboo fiber properties: case study of ethiopia species
}

\author{
Dawit Tessema Ebissa ${ }^{1,2} \cdot$ Tamrat Tesfaye $^{2} \cdot$ Delele Worku $^{1,3,4} \cdot$ David Wood $^{5}$
}

Received: 23 November 2021 / Accepted: 24 January 2022

Published online: 14 February 2022

(c) The Author(s) 2022 OPEN

\begin{abstract}
The mechanical properties of single Yushania alpina bamboo fibers have not been explored. This is a serious limitation on their application. The main purpose of this work is to fill up information gaps to prepare for the growing usage of Ethiopian bamboo in a variety of applications. This study looks at the characterization and optimization of Y.alpina bamboo fiber properties extracted both chemically and mechanically. Using response surface methodology (RSM) the mechanical properties were optimized and linear, quadratic and interaction of independent variables were determined. Samples of length $25-30 \mathrm{~cm}$ were harvested at various ages from the middle of the stem which was then soaked in different $\mathrm{NaOH}$ concentrations weight by volume for different times. Using a rolling machine that has three rollers, the fiber is mechanically extracted. The optimal mechanical properties were observed at plant age of 1.8 years, alkali concentration of $10 \%$, and a soaking duration of 2.0 days. The model is significant $(P \leq 0.005)$ with a $95 \%$ confidence level for predicted values that were closer to the measured values, indicating that the model's fit to the measured properties was strong at the optimized values. The optimized points of age and soaking duration ware subjected to chemical, thermal and morphological analysis for each corresponding $\mathrm{NaOH}$ Concentration $(6,12$, and $18 \%)$ levels. Scanning electron microscopy (SEM) was employed to examine the microstructure of the fibers and discovered that the $18 \% \mathrm{NaOH}$ treated fiber resulted in more wrinkles in the surface of bamboo fibers when compared with the 6 and $12 \% \mathrm{NaOH}$ Bamboo fiber. Using thermogravimetric analysis (TGA) and differential thermal gravimetric (DTG), the study investigated weight loss increased as alkali concentration increased but the scenario functioned for proper concentration.
\end{abstract}

Keywords Yushania alpina bamboo fiber $\cdot$ Alkali treatment $\cdot$ Characterization $\cdot$ Optimization $\cdot$ Mechanical properties

\section{Introduction}

Society's increased awareness of pollution in its many forms has led to increased use of natural instead of synthetic fibers for different applications in the energy, automotive, and textile industries. Other applications include construction materials, and home appliances [1]. Among these natural fibers, bamboo possesses a high strength-toweight ratio because of its longitudinally aligned fibers [2]. Chemically, bamboo is similar to wood with lignin, cellulose, and hemicelluloses accounting for more than $90 \%$ of the total bamboo mass [3]. The majority of previous studies considered bamboo fiber applications rather than their mechanical properties. Low-cellulose refined bamboo

$\triangle$ Dawit Tessema Ebissa, awwce2005@gmail.com | 'Bahir Dar Energy Center, Bahir Dar Technology Institute, Bahir Dar University, Bahir Dar, Ethiopia. ${ }^{2}$ Ethiopian Institute of Textile and Fashion Technology (EiTEX), Bahir Dar University, Bahir Dar, Ethiopia. ${ }^{3}$ Department of Material Science and Engineering, College of Science, Bahir Dar University, Bahir Dar, Ethiopia. ${ }^{4}$ Department of Chemistry, College of Science, Bahir Dar University, Bahir Dar, Ethiopia. ${ }^{5}$ Department of Mechanical and Manufacturing Engineering, University of Calgary, 2500 University Dr. NW, Calgary T2N 1N4, Canada.

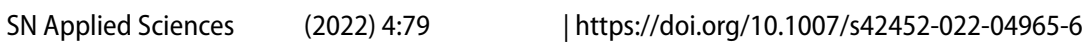


fiber can be used in textiles [4]. The possibility of developing economical bamboo Thailand textiles, motivated by the lack of weaving materials and the pollutants produced in their manufacture, and to replace imported weaving materials [5]. Due to the low alkali index, ash content, and hemicelluloses fiber properties, bamboo is suitable for bioenergy products including charcoal, biofuels, pyrolysis, gasification, briquettes, pellets, biomass, and bioethanol, through various production processes [6-8]. Bamboo is hard, lightweight, and has a high specific strength, tensile strength, and tensile modulus. Due to these properties, it is used for versatile construction materials, concrete and composite reinforcement, fencing, and housing [9-13]. Bamboo is suitable for pulverizing due to its form, chemical content, and structure. Paper produced from bamboo reduces the demand for wood and can cause less pollution in the manufacture [14]. Bamboo fiber pulp can be used to make newsprint, stickers, toilet paper, cardboard, cement bags, and coffee filters in the paper industry [15]. Y. alpina, which is Ethiopian indigenous bamboo species, suggested employing in the making of paper and suitable raw materials in the pulp industries [16]. The investigation on lowcost bamboo towers for small wind turbines explore that the characteristic properties of untreated bamboo and showed the potential for cost reduction for small wind towers [17]. The cellulose content of the fiber determines its mechanical properties, which is controlled by a variety of elements including fiber volume ratio, fiber length, yarn ratio, fiber-matrix adhesion or fiber orientation, plant age, fiber species type, and extraction procedures [18].

Bamboo species highly affect the mechanical properties as shown in Table 1. The study on the mechanical properties of different bamboo species: Bambussa balcooa, Bambusa tulda, Bambusa salarkhanii, and Melocanna baccifera, grown in southwestern Bangladesh was carried out at different ages and heights of sample collection [19]. The modulus of elasticity between bamboo species varies extensively and the modulus of elasticity values of the
Bambusa balcooa species changed significantly with age and height of collection [19]. The mechanical properties of bamboos at different ages (1, 3, and 5 years) were investigated by previous studies and explored that the bending and compressive strength improved as age increased [20].

Alkali treatment $(\mathrm{NaOH})$ caused gaps in the cell wall by reducing the diameter, lumen, and cross-sectional area of the bamboo fiber. With alkali treatment, individual bamboo fiber tensile strength and modulus of elasticity (MOE) decreased [23]. The mechanical characteristics of different species and bamboo plant ages were explored and it was shown that LV and Ma bamboo fibers reach their maximum tensile strength after one year [26]. At different $\mathrm{NaOH}$ concentration weight by volume $(6,8,10,15$, and $25 \%$ ), the tensile strength was $0.64,0.68,0.59$ and $0.61 \mathrm{Gpa}$ respectively. The concentration also affected the modulus of elasticity and elongation at failure of bamboo fiber, different methods have been used to extract bamboo fibers depending on their application [27]. These processes are classified as chemical and mechanical. In chemical extraction, the mechanical properties of bamboo fiber were affected by the soaking time of the fiber. The tensile strength at the different soaking times was $13.64,15.75$, $15.58 \mathrm{Nm} / \mathrm{g}$, and $15.36 \mathrm{Nm} / \mathrm{g}$, attained by soaking for $5 \mathrm{~min}, 10 \mathrm{~min}, 15 \mathrm{~min}$, and $20 \mathrm{~min}$ respectively $[28,29]$. An alkaline (e.g. $\mathrm{NaOH}$ ) or an acid (e.g. $\mathrm{HCl}$ ) is used to remove amorphous regions and reduce the lignin content of the fiber, In addition, this chemical treatment affects other components of the bamboo microstructure such as pectin and hemicelluloses. Mechanical methods involve various mechanical procedures such as; steam or autoclave sandblasting, high-pressure refining, grinding, rolling, and crushing [30]. These mechanical and other extraction methods have a significant effect on the mechanical properties as shown in Table 2.

Ethiopia has over 1.3 million hectares of bamboo, accounting for $67 \%$ of Africa's bamboo growing area and over $7 \%$ of the global bamboo area. Ethiopia has two
Table 1 the mechanical properties of different bamboo species

\begin{tabular}{lllllll}
\hline Species & $\begin{array}{l}\text { Breaking force } \\
\text { N }\end{array}$ & $\begin{array}{l}\text { Elongation } \\
\%\end{array}$ & $\begin{array}{l}\text { Tensile strength } \\
\text { Mpa }\end{array}$ & $\begin{array}{l}\text { Work done } \\
\text { cNmm }\end{array}$ & $\begin{array}{l}\text { Modulus } \\
\text { Gpa }\end{array}$ & $\begin{array}{l}\text { Refer- } \\
\text { ences }\end{array}$ \\
\hline Moso & 4.1 & - & 150.1 & - & 9.6 & {$[21]$} \\
Thorny & 5.1 & - & 195.5 & - & 7.8 & \\
Makino & 3.5 & - & 137.76 & - & 10.2 & \\
G.S.Gamble & - & - & 368.3 & - & 22 & {$[22]$} \\
B.vulgaris & - & 7.7 & 366.8 & - & 3.8 & {$[3]$} \\
N.affinis & - & 8.21 & 590 & - & 8.9 & {$[23]$} \\
Bambusa vulgaris & - & - & 339 & - & - & {$[24]$} \\
Vulgaris & 3.58 & 3.98 & 212 & & 5.3 & {$[25]$} \\
Y.alpina & 7.8 & 2 & 411.7 & 516.3 & 17.7 & Measured \\
\hline
\end{tabular}

$1 \mathrm{~N}=100 \mathrm{cN}, 1 \mathrm{Mpa}=0.111 \mathrm{cN} / \mathrm{tex}$ 
Table 2 Effect of extraction technique on the fiber properties [31-34]

\begin{tabular}{|c|c|c|c|c|}
\hline Type of treatment & Parameter of treatment & Strength(Mpa) & Modulus (Gpa) & Elongation (\%) \\
\hline Mechanical & $\begin{array}{l}\text { First, a roller crusher, then a pin roller, and last, a 10-h } \\
\text { boil at } 90^{\circ} \mathrm{C}\end{array}$ & $420 \pm 170$ & $38.2 \pm 16$ & $9.8 \pm 2.5$ \\
\hline Steam explosion & heated for 9 times at $175^{\circ} \mathrm{C}, 0.8 \mathrm{MPa}$ & 383 & 28 & 2.82 \\
\hline Chemical & $\mathrm{NaOH}$ solution of higher concentration & 329 & 22 & 2.35 \\
\hline Alkali + mechanical & $1.5 \mathrm{~N} \mathrm{NaOH}$, heated at $70^{\circ} \mathrm{C}$ for $5 \mathrm{~h}$, pressed machine & 419 & 30 & 2.67 \\
\hline
\end{tabular}

common bamboo species, Y.alpina (highland bamboo) and the Abyssinica Oxytenantheria (lowland bamboo) [35]. Highland bamboo grows in Ethiopia's southern, southwestern, central, and northwestern highlands and covers an estimated 300,000 hectares [36].

The thermal stability or decomposition behavior of alkali-treated Y.alpina bamboo fiber at different concentrations was investigated by thermogravimetric analysis (TGA). All of the alkali-treated bamboo fibers exhibited distinct weight loss (decomposition stages). Three thermal decomposition stages characterized the total degradation profile of bamboo fiber, namely moisture evaporation, cellulose decomposition, and lignin decomposition [37]. The first stage of weight loss is referred to as the dehydration stage. which mentioned moisture evaporation from the fiber structure. Whereas the rest stages are linked to the degradation of polysaccharides such as cellulose, hemicelluloses, and lignin [38, 39]. Hemicelluloses start to degrade earlier and decompose in the range $220-350^{\circ} \mathrm{C}$. The low thermal stability of hemicelluloses is assumed to be due to a lower degree of polymerization compared to cellulose and lignin $[40,41]$.

The mechanical properties of bamboo are mainly provided by the cellulose content, which is influenced by many factors such as fiber volume fraction, fiber length, fiber aspect ratio, fiber-matrix adhesion or fiber orientation, plant age, plant height, species type, and extraction methods[42-46]. However, the research focuses on the characterization and optimization of mechanical properties of alkali-treated Y.alpina single fiber properties. Because the remainder of the parameters is in the composite case, the study used plant age, alkali content, and soaking duration as factors for the RSM design.

The mechanical properties of Y.alpina single fibers have not been examined. This is a serious limitation on their use. The main aim of this study is to remedy this lack of information in anticipation of the increasing use of Ethiopian bamboo in a variety of applications. In the stage of surface-modified fibers, alkali treatment is currently applied. The material is immersed in an alkaline solution at various concentrations during the process.

In this experimental study, bamboo fiber (Y.alpina) was obtained through alkali treatment at different plant ages
$(1,2$, and 3 years), concentrations weight by volume $(6,12$, and $18 \%)$, and soaking durations (1,2, and 3 days) were tested using a universal testing machine and optimized the best mechanical properties using Design Expert ${ }^{\circledR} 11$ (Stat-Ease Inc, Minneapolis, USA) by compared with the interaction results of different variables.

\section{Materials and methods}

\subsection{Materials}

\subsubsection{Bamboo sample}

The bamboo species used in the experiments is Y.alpina (Fig. 1). Bamboo stem samples were obtained from 1 to 3 years-old plantations in Enjibara (latitude: $10,057^{\prime} \mathrm{N}$, longitude: 36,056' $\mathrm{E}$, and elevation $2560 \mathrm{~m}$ above sea level), Awi region, West Gojam, Amhara region, Ethiopia.

\subsubsection{Chemicals}

sodium hydroxide( $\mathrm{NaOH}$, manufacturer: RESEARCH-LAB FINE CHEM INDUSTRIES, Assay: min98\%) at a different

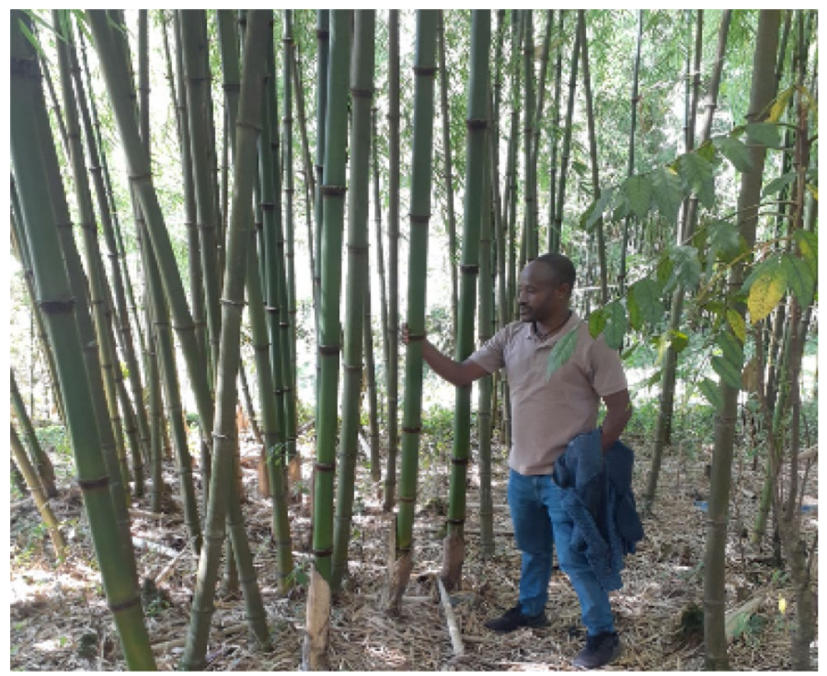

Fig. 1 Y.alpina bamboo plant in Ethiopia 
concentration weight by volume of 6,12 , and $18 \%$ and soaking duration of 1,2 , and 3 days.

\subsection{Methods}

\subsubsection{Raw material preparation}

On collection, the bamboo sections were a wet mass of various residues. They were cleaved with a slicer at the middle stem around $25-30 \mathrm{~cm}$ in length, and $2.0-2.5 \mathrm{~mm}$ thickness to remove residual parts and prepare bamboo strips.

\subsubsection{Chemical analysis}

The following methods were used to determine the chemical composition of Y.alpina. The chemical compositions of lignin and hemicellulose content were determined using ASTM standards. The cellulose content was determined using the Kurschner-Hoffer method. The experiment was repeated three times.

\subsubsection{Proximate analysis}

The proximate chemical analysis was performed to estimate moisture content, volatile matter content, ash content, and fixed carbon content. In porcelain crucibles, $1.0 \mathrm{~g}$ samples were used. All of the tests were carried out in triplicate.

\subsubsection{Moisture content}

At $105^{\circ} \mathrm{C}$ for $1 \mathrm{~h}$, samples were placed in an oven (KEMI Model: KOA.6.F, INDIA) until they reached a consistent mass. Equation 1 was used to determine the moisture $(\mathrm{Mc})$ content of the samples using the ASTM E 871 standard and wet basis moisture content.

$M c=\frac{m_{1}-m_{2}}{m_{1}} \times 100$

Mc: Moistur content(\%), $\mathrm{m}_{1}$ :Wet mass(g), $\mathrm{m}_{2}$ : Dry mass(g).

\subsubsection{Volatile matter content}

Dry samples were placed in a Box-type resistance furnace (Model: BK-5-12GJ) for seven minutes at $950^{\circ} \mathrm{C}$. The samples were weighed after cooling in a desiccator and determined the volatile matter content using the ASTM E872 standard using Eq. 2.

$\operatorname{Mvm}=\frac{m_{2}-m_{3}}{m_{1}} \times 100$

Mvm: Volatile matter content (\%), m3: Dry sample weight(g) after placed in an oven at $950^{\circ} \mathrm{C}$ for $7 \mathrm{~min}$.

\subsubsection{Ash content}

The identical material used in the analysis of ash content was taken to a Box-type resistance furnace (Model: BK$5-12 \mathrm{GJ}$ ) at $750^{\circ} \mathrm{C}$ for 30 min until it reached constant mass, according to the ASTM E1755standard. It is assumed that only ashes remain inside the crucible at the end of this process.

$M a=\frac{m_{4}}{m_{1}} \times 100$

Ma: Ash content (\%), $\mathrm{m}_{4}$ : Ash weight(g).

\subsubsection{Fixed carbon content}

For moisture, ash, and volatile matter, conducted a proximate analysis based on ASTM standards E 871, E 1755, and E 872, respectively. fixed carbon content calculated using Eq. 4.

$F_{C C}=100-[M c+M v m+M a]$

$\mathrm{F}_{\mathrm{CC}}$ : Fixed carbon content (\%).

\subsubsection{Ultimate analysis}

An elemental analyzer (Model: EA 1112 Flash CHNS/Oanalyzer) was used to determine the contents of carbon, hydrogen, nitrogen, and sulfur with a carrier gas flow rate of $120 \mathrm{ml} / \mathrm{min}$, a reference flow rate of $100 \mathrm{ml} / \mathrm{min}$, and an oxygen flow rate of $250 \mathrm{ml} / \mathrm{min}$; a furnace temperature of $900^{\circ} \mathrm{C}$, and an oven temperature of $75^{\circ} \mathrm{C}$. the oxygen content was calculated by subtracting the sum of carbon, hydrogen, nitrogen, and sulfur components.

\subsubsection{Extraction}

The following combinations of chemical and mechanical methods fiber extraction were used; soaked the bamboo strips with $\mathrm{NaOH}$ concentrations (6-18\% w/v), plant age ( $1-3$ years), and soaking duration ( $1-3$ days). After soaking, the fibers were washed with tap water until the solution was neutralized. Then a roller crusher machine (PHOENIX, Belgium Products) was utilized to extract small fibers from the alkali-treated bamboo strips. the extracted fibers (Fig. 2) were dried at $105^{\circ} \mathrm{C}$ oven for $1 \mathrm{~h}$.

\section{Experimental design}

The subset of the response surface methodology (RSM) design known as the Box-Benhken design (BBD) was used to determine the main effects and interactions of 

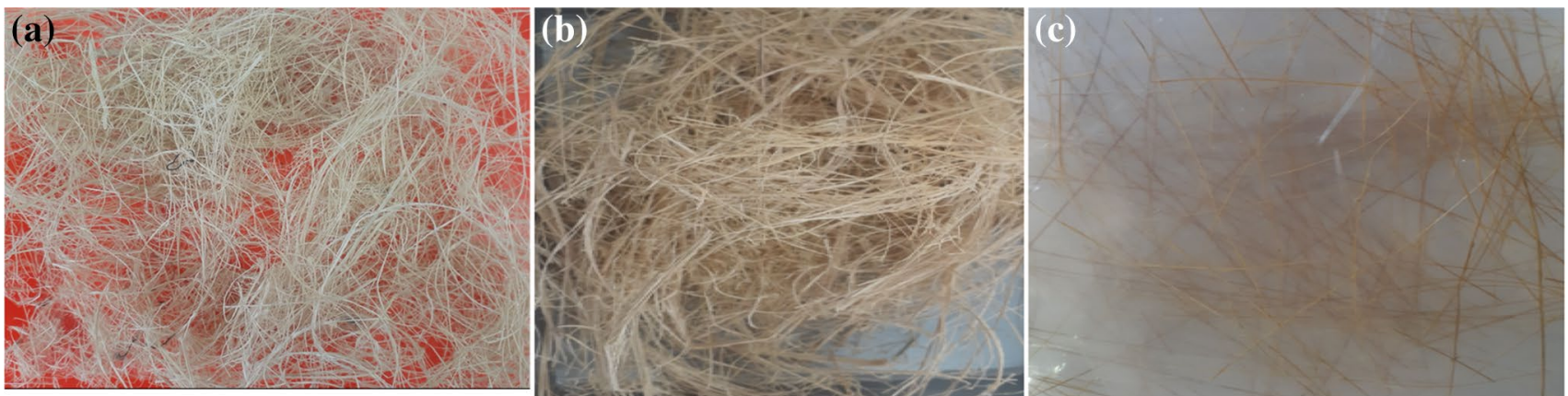

Fig. 2 Y.alpina bamboo fiber $\mathbf{a}$ Untreated $\mathbf{b}$ Treated $\mathbf{c}$ Treated fiber testing sample hold on a plastic holder

Table 3 Design layout of independent variables and coded values

\begin{tabular}{llllll}
\hline Factors & Symbol & Unit & \multicolumn{2}{c}{ Range and level } \\
\cline { 3 - 6 } & & & Low $\begin{array}{c}\text { Middle/ } \\
\text { Central }\end{array}$ & High \\
& & & -1 & 0 & 1 \\
\hline Plant age & A & Year & 1 & 2 & 3 \\
NaOH Concentration & B & $\%$ & 6 & 12 & 18 \\
Soaking duration & C & Day & 1 & 2 & 3 \\
\hline
\end{tabular}

the variables of independent processes as well as the model equations for each dependent variable to extend the application of the proposed process and optimize the process parameters [47-49]. Using BBD can strongly decrease the number of experimental sets without diminishing the exactness of the optimization compared with conventional factorial design methods [50]. The study presents by focusing on the effect of plant age, alkali concentration, and soaking time on the mechanical properties because in the case of alkali-treated single fibers the cellulose content is highly affected by these factors $[26,46,51,52]$. All variables (plant age, $\mathrm{NaOH}$ concentration, and soaking time) can be coded as, low $(-1)$ medium $(0)$, and high $(+1)$. The extent and extent of each independent factor based on BBD were presented in Table 3.

Design Expert ${ }^{\oplus} 11$ was utilized within the plan lattice and examination of the test information. 13 experiments with 5 central points per block were carried out, as shown in Table 4.

The relationship between the independent variables of plant age $(A)$, concentration $(B)$, and soaking time $(C)$, and responses ' $y$ ' (breaking force, elongation, tenacity, work done, and modulus) were fit to the 3-factor polynomial model:

$y=\beta_{0}+\beta_{1} A+\beta_{2} B+\beta_{3} C+\beta_{12} A B+\beta_{11} A^{2}+\beta_{22} B^{2}+\beta_{33} C^{2}+\beta_{13} A C+\beta_{23} B C+\beta_{123} A B C$

Table 4 Experimental design factors and responses values from design expert 11

\begin{tabular}{lllllllll}
\hline Run & $\begin{array}{l}\text { A } \\
\text { Year }\end{array}$ & $\begin{array}{l}\text { B } \\
\%\end{array}$ & $\begin{array}{l}\text { C } \\
\text { Day }\end{array}$ & $\begin{array}{l}\text { Breaking Force } \\
\text { cN }\end{array}$ & $\begin{array}{l}\text { Elongation } \\
\%\end{array}$ & $\begin{array}{l}\text { Tenacity } \\
\text { cNtex }^{-1}\end{array}$ & $\begin{array}{l}\text { Work done } \\
\text { cNmm }\end{array}$ & $\begin{array}{l}\text { Modulus } \\
\text { cNtex }^{-1}\end{array}$ \\
\hline 1 & 2 & 12 & 2 & 780.8 & 2.0 & 45.9 & 508.2 & 1876 \\
2 & 1 & 6 & 2 & 574.8 & 1.7 & 33.8 & 414.6 & 2463 \\
3 & 2 & 6 & 1 & 460.1 & 1.3 & 27.1 & 139.4 & 1588 \\
4 & 1 & 12 & 1 & 417.9 & 0.8 & 24.6 & 95.6 & 1748 \\
5 & 3 & 12 & 1 & 491.8 & 1.8 & 28.9 & 166.3 & 911.7 \\
6 & 1 & 18 & 2 & 460.7 & 1.3 & 27.1 & 161.8 & 1416 \\
7 & 3 & 18 & 2 & 569.6 & 1.3 & 33.5 & 238.7 & 1748 \\
8 & 3 & 6 & 2 & 449.3 & 1.1 & 26.4 & 146.9 & 1449 \\
9 & 2 & 6 & 3 & 616.7 & 1.2 & 36.2 & 276.6 & 1943 \\
10 & 1 & 12 & 3 & 374.5 & 1.0 & 22.0 & 99.5 & 1319 \\
11 & 2 & 18 & 1 & 326.1 & 0.7 & 19.2 & 54.2 & 1516 \\
12 & 2 & 18 & 3 & 484.3 & 0.9 & 28.5 & 125.4 & 1978 \\
13 & 3 & 12 & 3 & 363.3 & 0.8 & 21.4 & 57.3 & 1582 \\
\hline
\end{tabular}


where $\beta_{0}$ is the constant term, $\beta_{i}, \beta_{i j}$, and $\beta_{i j k}$ are the coefficients of the various order terms.

\subsection{Characterization}

Mechanical properties (breaking force, elongation, tenacity, work done, and modulus) of 13 samples were examined based on design expert software recommendations. The tests were carried out according to ISO 13934-1: 2013 testing standard by a semi-automatic tenso lab tensile testing machine. The available load cells were 20, 100, 500, $1000 \mathrm{~N}$, and $5000 \mathrm{~N}$. At stable conditions, the speed and force measurement accuracy of the machine are $\pm 0.01 \%$ and $\pm 0.03 \%$ respectively. The capacity of the load cell used was $20 \mathrm{~N}$ with a force maximum resolution of $0.0002 \mathrm{cN}$. The gauge length of the measurement is $50 \mathrm{~mm}$ and the testing speed range is $0.001-1000 \mathrm{~mm} / \mathrm{min}$. The samples were aligned and an axial tensile load was then applied. No rotation or translation of the sample was allowed. The mechanical properties (responses) were recorded up to failure which often started with a small notch-like crack or splitting in the sample.

The chemical and thermal characterization were carried out on the optimized points of age and soaking duration (1.8 years ago, 2.0 days soaking duration) that generated the optimal mechanical properties were subjected to FTIR, TGA, DTG, and SEM analysis for each corresponding $\mathrm{NaOH}$ Concentration $(6,12$, and $18 \%$ ) levels.

The functional groups and other impurities were identified using Fourier transform infrared spectroscopy (JASCO MODEL FT-IR 6660) analysis in the wave range of $4000-400 \mathrm{~cm}^{-1}$. The thermal stability studied was done by thermogravimetric (BJHENVEN HCT-1) Analysis with the temperature ranging from 20 to $700{ }^{\circ} \mathrm{C}$ at a rate of $20^{\circ} \mathrm{C}$ per minute in an air atmosphere. Scanning electron microscopy (JCM_6000 PLUS) illustrated the morphological variations due to the alkali treatment of fibers with a random orientation at different concentrations with various magnifications and an acceleration voltage of $10 \mathrm{kV}$.

\section{Results and discussion}

\subsection{Raw materials chemical analysis}

For improved mechanical properties, the bamboo plant which has high hemicellulose and cellulose content and low lignin content is preferred [53]. Table 5 shows the main chemical composition of the Y. alpina bamboo and its comparison to other bamboo species. The table exhibited that the chemical composition ranged cellulose $37.21-53.50 \%$, hemicellulose $12.18-21.6 \%$, and lignin $21.3-25.27 \%$. The findings of this study indicated that cellulose (51.06\%),
Table 5 Main chemical composition analysis of Y.alpina compared with other different bamboo species

\begin{tabular}{lllll}
\hline Species & Cellulose (\%) & $\begin{array}{l}\text { Hemi- } \\
\text { cellulose } \\
(\%)\end{array}$ & Lignin (\%) & Reference \\
\hline Haur hejo & 52.3 & 19.15 & 20.01 & {$[54]$} \\
Tali & 46.91 & 17.29 & 21.3 & \\
P.heterocycla & 37.21 & 21.6 & 24.29 & {$[55]$} \\
O.abyssinia & 52.06 & 16.90 & 22.47 & {$[56]$} \\
Y.alpina & 46.76 & 12.18 & 25.27 & {$[57]$} \\
Y.alpina & 53.50 & 18.10 & 24.20 & {$[16]$} \\
Y.alpina & 51.06 & 20.19 & 23.79 & Measured \\
\hline
\end{tabular}

hemicellulose (20.19\%), and lignin (23.79\%) in Y.alpina bamboo species, had good cellulose and hemicellulose content so had good mechanical qualities.

The proximate and ultimate chemical analyses of the bamboo species Y.alpina as well as comparisons to other bamboo species are shown in Table 6 . The moisture content of all species ranged from 7.1 to $18 \%$. From the previous studies' results, Malaysia Bamboo showed higher moisture content (15.3\%), while the Betung bamboo presented a lower value $(7.1 \%)$. The bamboo species used in this study exhibited the highest value of moisture content $(18 \%)$. This is a reasonable result considering the result of observing the high thickness of the woody part and growing weather. As seen in Table 6, the ash content ranged from 1.02 to $3.29 \%$, with Y.alpina having the lowest value and G.atrovio having the highest value. Therefore Y.alpina is suitable for thermal use because it has low ash content. A species with a higher ash concentration has a lower calorific value. The bamboo species are considered in this study to have a fixed carbon content of $7.28 \%$ and volatile matter of $73.70 \%$. As the temperature increased, the fixed carbon content increased but the volatile carbon content declined. In the combustion process, nitrogen and sulfur in fuel can produce polluting gases, such as NOx and SOx. As shown in Table 6, all bamboo species including Y.alpina, contain less than $1 \%$ nitrogen and sulfur respectively, indicating that using bamboo as a source of energy does not result in significant air pollution. The amount of carbon and hydrogen content in the bamboo culm is very satisfactory as they contribute immensely to the combustibility of any substance in which they are found.

\subsection{FT-IR analysis}

The chemical structures of 2 years age Y.alpina bamboo fibers treated with $6-18 \% \mathrm{NaOH}$ soaking for 2 days were investigated using FTIR. For clarity, the FTIR spectra were shifted vertically using Software Origin, as shown in Fig. 2 All of the samples' results showed typical spectra 
Table 6 Proximate and ultimate analysis of Y.alpina compared with other different bamboo species

\begin{tabular}{|c|c|c|c|c|c|c|c|c|c|c|}
\hline \multirow[t]{2}{*}{ Species } & \multicolumn{4}{|c|}{ Proximate analysis (\%) } & \multicolumn{5}{|c|}{ Ultimate analysis (\%) } & \multirow[t]{2}{*}{ Reference } \\
\hline & Moisture & VM & Ash & FC & $\mathrm{C}$ & $\mathrm{N}$ & $\mathrm{O}$ & $\mathrm{H}$ & $S$ & \\
\hline Malaysia Bamboo & 15.30 & 70.12 & 1.76 & 11.32 & 38.40 & - & - & - & 0.07 & {$[58]$} \\
\hline G.apus & 8.89 & 70.13 & 2.45 & 18.35 & 44.29 & 0.53 & 46.47 & 6.16 & 0.10 & {$[59]$} \\
\hline G.levis & 8.76 & 72.71 & 2.46 & 16.07 & 44.65 & 0.48 & 45.97 & 6.35 & 0.09 & \\
\hline G.atrovio & 8.13 & 71.70 & 3.29 & 16.88 & 44.11 & 0.47 & 45.8 & 6.26 & 0.07 & \\
\hline Andong & 8.40 & 78.00 & 2.08 & 11.5 & 49.00 & 0.40 & 44.40 & 6.09 & 0.05 & {$[60]$} \\
\hline Hitam & 7.80 & 72.40 & 1.36 & 18.4 & 50.30 & 0.46 & 42.90 & 6.21 & 0.05 & \\
\hline Tali & 7.30 & 80.00 & 1.89 & 10.8 & 50.90 & 0.24 & 42.30 & 6.44 & 0.07 & \\
\hline Kuning & 7.60 & 75.40 & 2.68 & 14.3 & 48.20 & 0.39 & 45.20 & 6.08 & 0.05 & \\
\hline Ampel & 10.20 & 72.00 & 1.15 & 16.70 & 49.50 & 0.43 & 43.70 & 6.30 & 0.04 & \\
\hline Betung & 7.10 & 75.40 & 2.44 & 15.10 & 48.70 & 0.33 & 44.90 & 6.00 & 0.05 & \\
\hline Y.alpina & 18.00 & 73.70 & 1.02 & 7.28 & 43.21 & 0.37 & 49.83 & 6.50 & 0.09 & Measure \\
\hline
\end{tabular}

VM Volatile matter, FC Fixed carbon, $C$ Carbon, $N$ Nitrogen, $O$ Oxygen, $H$ Hydrogen, $S$ Sulphur

\begin{tabular}{|c|c|c|}
\hline Wavenumber $\left(\mathrm{cm}^{-1}\right)$ & Functional group & Compounds \\
\hline $3434-3415$ & $-\mathrm{OH}$ & $\begin{array}{l}\text { Alcohol(cellulose; hemi-cellulose; lignin), phenol } \\
\text { (bond H), carboxylic acid }\end{array}$ \\
\hline $2926-2922$ & $\mathrm{C}-\mathrm{H}$ & Alkanes \\
\hline $1621-1619$ & $\mathrm{C}=\mathrm{O}$ & hemicelluloses and lignin \\
\hline $1387-1386$ & $\mathrm{C}-\mathrm{H}$ & $\mathrm{C}-\mathrm{H}$ deformation in cellulose and hemicelluloses \\
\hline 1110 & $\mathrm{C}-\mathrm{O}$ & $\begin{array}{l}\text { Alcohol (cellulose; hemicellulose; lignin), ether, } \\
\text { carboxylic acid, ester }\end{array}$ \\
\hline $618-616$ & $\mathrm{O}-\mathrm{H}$ & out of plane bending \\
\hline
\end{tabular}

Table 7 Characteristic bands for a functional group of alkali-treated Y.alpina bamboo fiber at various concentrations [64-69]

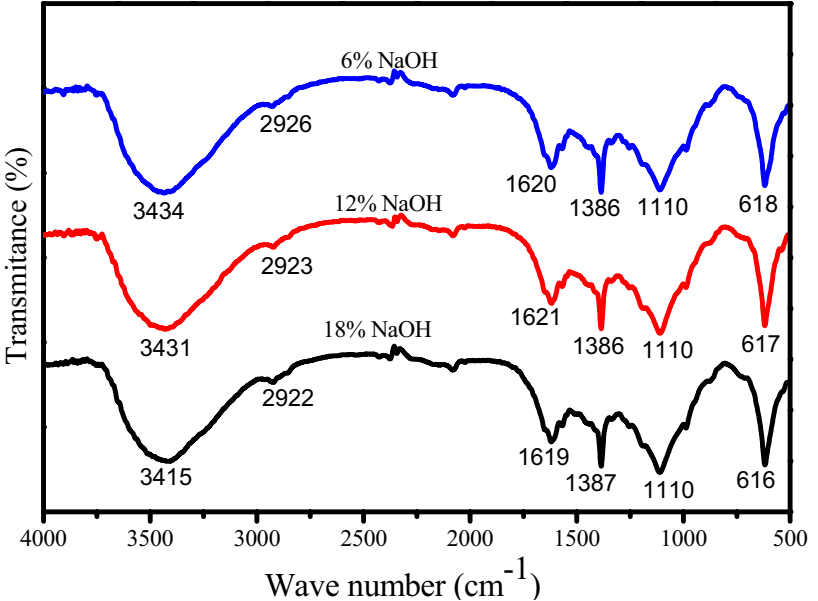

Fig. 3 FTIR analysis of alkali-treated Y.alpina bamboo fiber at different concentration

weight loss of Y.alpina bamboo fiber treated with $12 \%$ $\mathrm{NaOH}$ concentration during the dehydration stage is $8.8 \%$, which is smaller than the $6 \% \mathrm{NaOH}$ concentration ( $20 \%$ weight loss). The presence of water in the fiber was found to be reduced after an increase in the concentration 


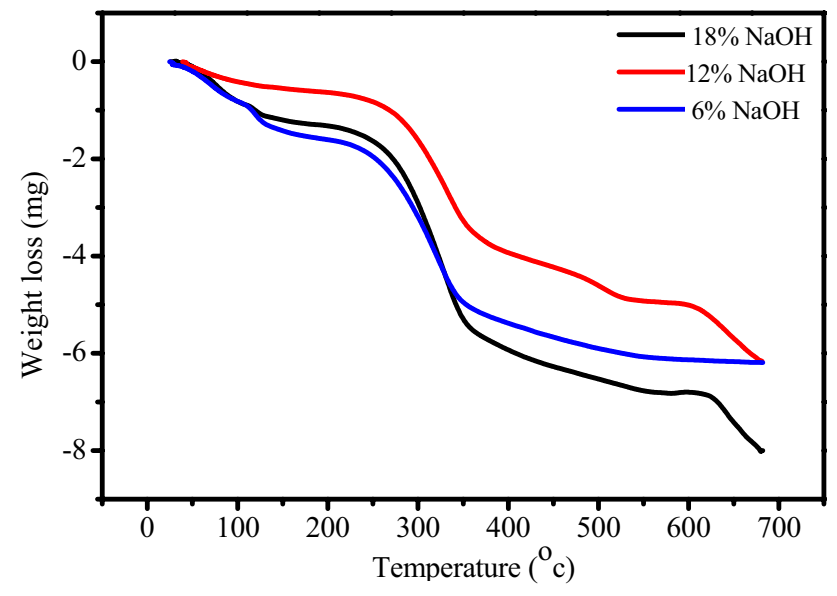

Fig. 4 TGA analysis of alkali-treated Y.alpina bamboo fiber with various $\mathrm{NaOH}$ concentrations

of alkali [70]. This phenomenon occurs as the alkali-sensitive components (active sites for moisture uptake) are eliminated by alkali treatment, resulting in a decrease in hydrophilicity and moisture absorption in the fiber [37]. even though this scenario happened as a result of proper concentration, weight loss increased to $17.5 \%$ when concentration was raised to $18 \%$. The pattern shown above is similar to that described in the earlier report on bamboo fiber thermal properties. The decomposition of hemicelluloses, cellulose, and lignin correspondingly caused the weight loss of bamboo fibers in the first, second, and third degradation stages [63].

Maximum temperature $\left(T_{\max }\right)$ is the decomposition temperature that corresponds to the maximum weight loss and decomposition rate, as well as a key indicator of the materials' thermal stability [71]. As shown in Table 8, the maximal decomposition temperature of Y.alpina bamboo fibers treated with $6 \% \mathrm{NaOH}$ is $355^{\circ} \mathrm{C}$. The maximal decomposition temperature climbed to $368^{\circ} \mathrm{C}$ when the $\mathrm{NaOH}$ concentration was increased to $12 \%$. It was discovered that alkali treatment with proper concentration can improve the thermal stability of individual bamboo fibers. However, the highest decomposition temperature was reduced to $353{ }^{\circ} \mathrm{C}$ when treated with alkali at a greater concentration of $18 \%$. This maximum temperature and weight loss discussion is also confirmed with DTG analysis as shown in Fig. 5. The onset temperature of decomposition shifted to a lower temperature as well [38]. This experimental investigation concluded that among the $6-18 \% \mathrm{NaOH}$ treated y.alphina bamboo fibers, $12 \% \mathrm{NaOH}$ concentration has optimal thermal stability properties.

\section{Morphological analysis}

Figures 6 and 7 exhibited the surface morphology of randomly arranged alkali-treated Y.alpina bamboo fibers with various $\mathrm{NaOH}$ concentrations. Figure 6 demonstrated the diameter of individual bamboo fibers decreased as the $\mathrm{NaOH}$ concentration increased. The dimension change of fiber possibly resulted from the loss of hemicelluloses and lignin matrix and also microfibrils aggregations with alkali treatment. Similar conduct was also observed in Neosinocalamus affinis bamboo fiber [23]. As shown in Fig. 7, the $18 \% \mathrm{NaOH}$ treated fiber resulted in more wrinkles in the surface of bamboo fibers when compared with the 6 and $12 \% \mathrm{NaOH}$ Bamboo fiber. This is due to the change

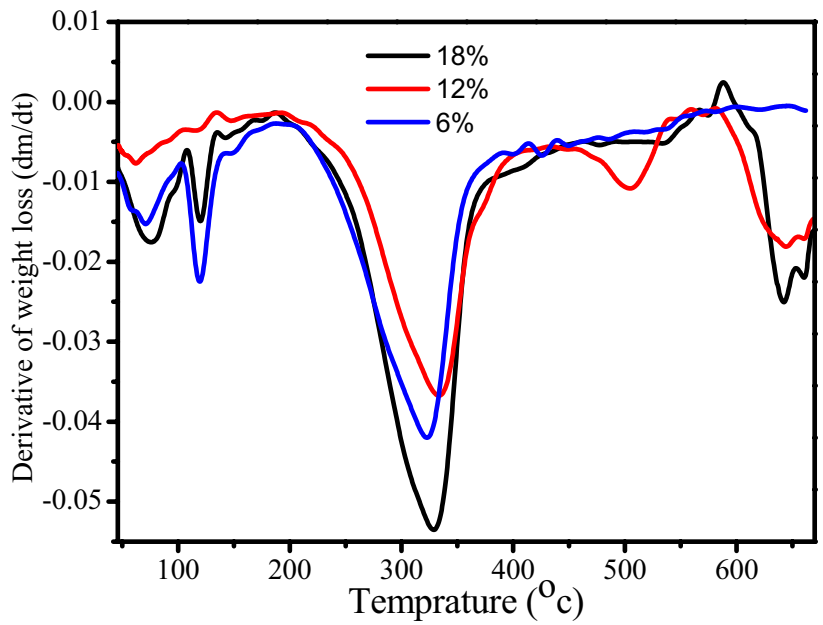

Fig. 5 DTG analysis of alkali-treated Y.alpina bamboo fiber with various $\mathrm{NaOH}$ concentrations
Table 8 Thermal stability data of alkali-treated Y.alpina bamboo fiber with various $\mathrm{NaOH}$ concentrations

\begin{tabular}{|c|c|c|c|c|c|c|c|c|c|}
\hline \multirow[t]{3}{*}{ Stages } & \multicolumn{3}{|l|}{$6 \% \mathrm{NaOH}$} & \multicolumn{3}{|c|}{$12 \% \mathrm{NaOH}$} & \multicolumn{3}{|c|}{$18 \% \mathrm{NaOH}$} \\
\hline & \multirow{2}{*}{$\begin{array}{l}\mathrm{T} \\
{ }^{\circ} \mathrm{C}\end{array}$} & \multicolumn{2}{|c|}{ Weight loss } & \multirow{2}{*}{$\begin{array}{l}\mathrm{T} \\
{ }^{\circ} \mathrm{C}\end{array}$} & \multicolumn{2}{|c|}{ Weight loss } & \multirow{2}{*}{$\begin{array}{l}\mathrm{T} \\
{ }^{\circ} \mathrm{C}\end{array}$} & \multicolumn{2}{|c|}{ Weight loss } \\
\hline & & $\mathrm{Mg}$ & $\%$ & & $\mathrm{mg}$ & $\%$ & & $\mathrm{mg}$ & $\%$ \\
\hline Dehydration & $\leq 212$ & 1.6 & 20 & $\leq 220$ & 0.7 & 8.8 & $\leq 213$ & 1.4 & 17.5 \\
\hline 1st Degradation & $212-355$ & 3.4 & 42.5 & $220-368$ & 2.9 & 36.3 & $213-353$ & 4.0 & 50.0 \\
\hline 2nd Degradation & $355-574$ & 1.1 & 13.8 & $368-588$ & 1.4 & 17.5 & $353-573$ & 1.4 & 17.5 \\
\hline 3rd Degradation & $574-680$ & 0.09 & 1.13 & $588-680$ & 1.19 & 14.9 & $573-680$ & 1.2 & 15.0 \\
\hline
\end{tabular}



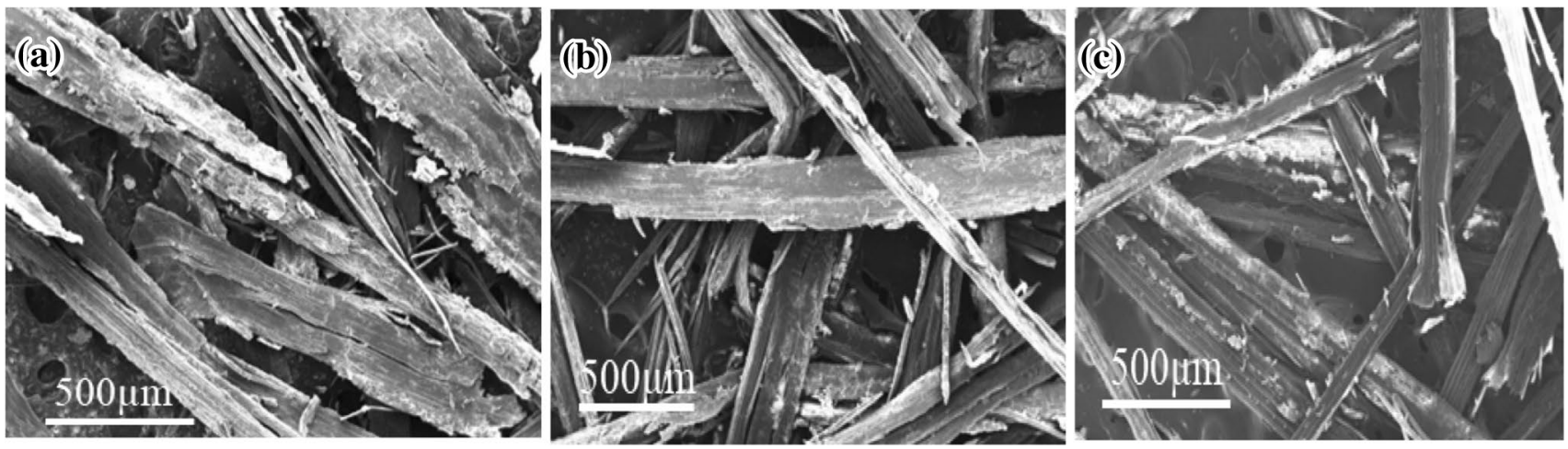

Fig. 6 SEM image of a $6 \%$ b $12 \%$ c $18 \%$ alkali treated Y.alpina bamboo fiber micromorphology
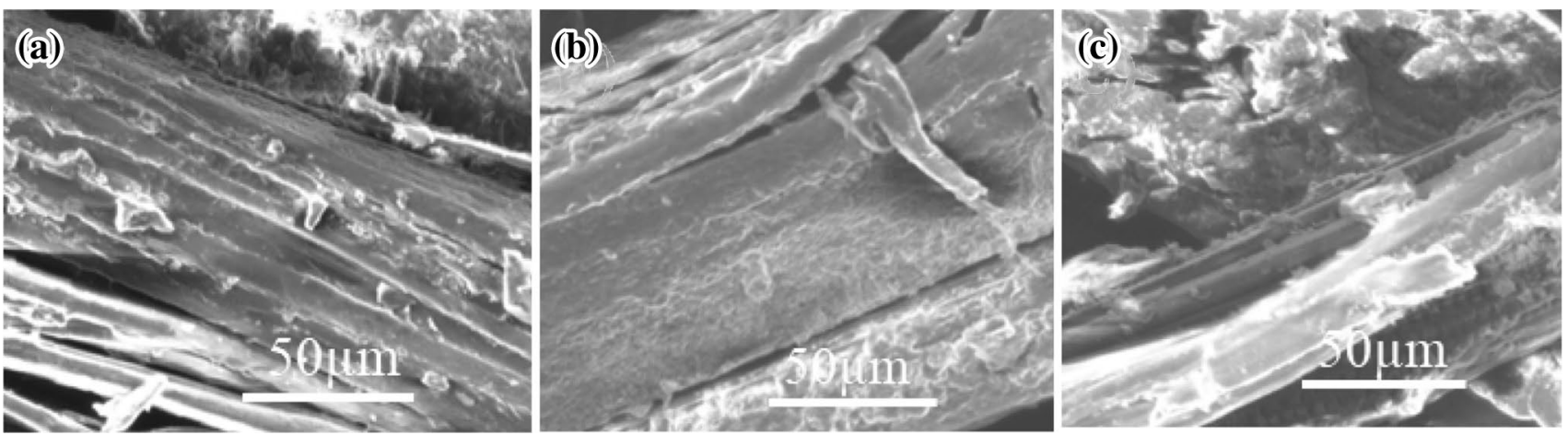

Fig. 7 SEM image of a $6 \%$ b $12 \%$ c $18 \%$ alkali treated Y.alpina bamboo fiber micromorphology

of the microfibril aggregates from a randomly interwoven structure to a granular structure. When the alkali concentration is increased, the surface morphological roughness increases due to the elimination of hemicelluloses lignin and other surface impurities Fig. 7. Because they provide good interfacial bonding between the polymer matrixes, these rough surfaces have more advantages in the fabrication of composite materials [72]. The partial loss of cellulose causes a decrease in fiber strength after treatment with high alkali concentrations. Hence an excessive concentration alkali treatment can damage the strength of single cellulosic bamboo strips [73]. There were also holes and grooves as shown in the figures, indicating that the alkali treatment was capable of removing considerable amounts of soluble elements from the layers.

\section{Mechanical properties}

The mechanical properties (breaking force, elongation, work done, modulus, and tenacity) of bamboo were affected by plant age. Elongation and modulus were not altered as much as breaking force, tenacity, and work done. These mechanical properties increased with age until two years, after which they were reduced as shown in Fig. 8. This discovery is in line with the findings of a previous study of Moso bamboo (Phyllostachys hetero-cyclavar. pubescens) [46]. There was no significant difference in modulus with age, however, there were significant differences in tensile strengths of Lv and Ma (Dendrocalamopsis oldhami and Dendrocalamus latiflorus Munro) bamboo [26].

In this investigation, the alkali treatment was found to have a substantial impact on mechanical properties due to changes in fiber structure which is consistent with the previous study results [23]. The mechanical properties, except for modulus, increased when concentration was increased up to $12 \%$ and then decreased. The changes, however, were small as shown in Fig. 9.

With longer soaking, all the mechanical properties were increased. However, breaking force, elongation, tenacity, and work done declined quicker than modulus when the soaking duration was longer than 2 days as shown in Fig. 10. These findings are similar to those of a prior study [27].

The two-dimensional (2D) contour impacts of the input parameters on the mechanical behaviour were shown in 


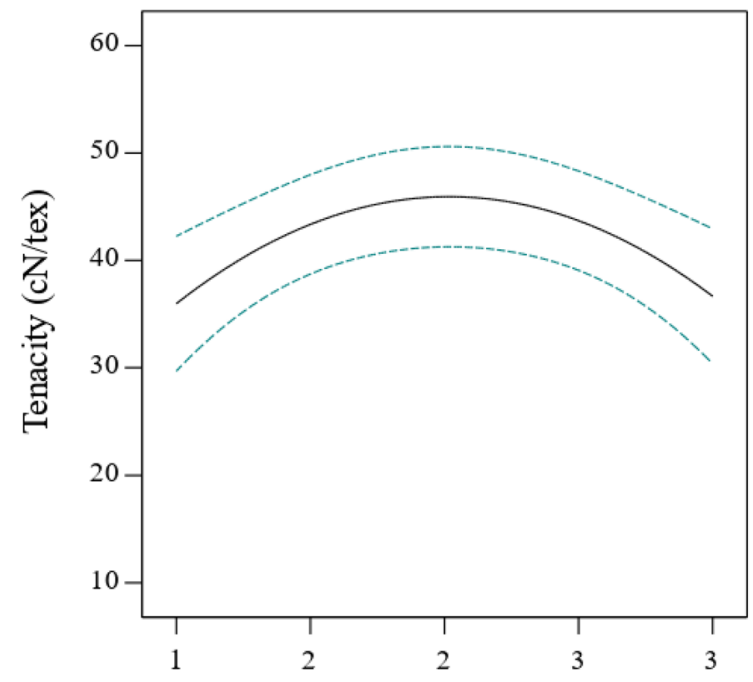

Age (Year)

(a)

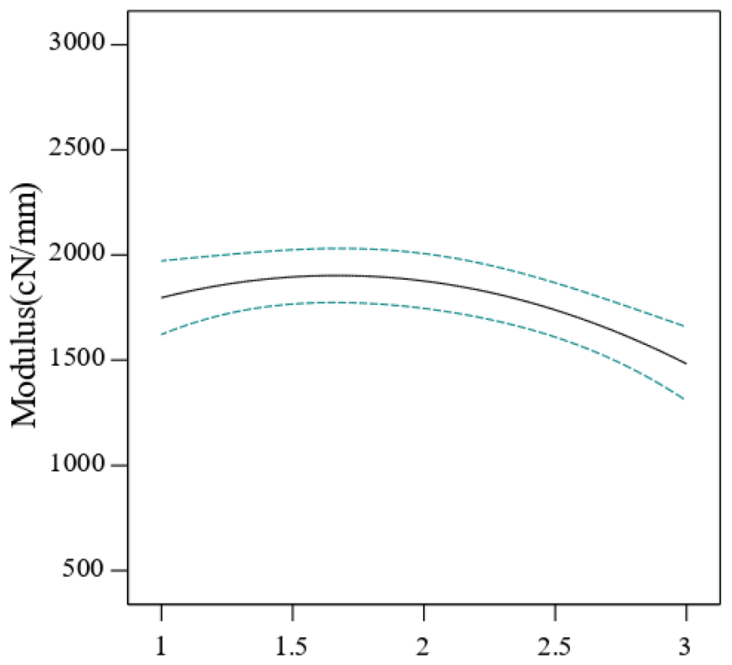

Age(Year)

(b)

Fig. 8 Eq. (1) for concentration 12\% and soaking time 2 days, solid line Dash lines show one standard deviation. a Age versus Tenacity b Age versus Modulus

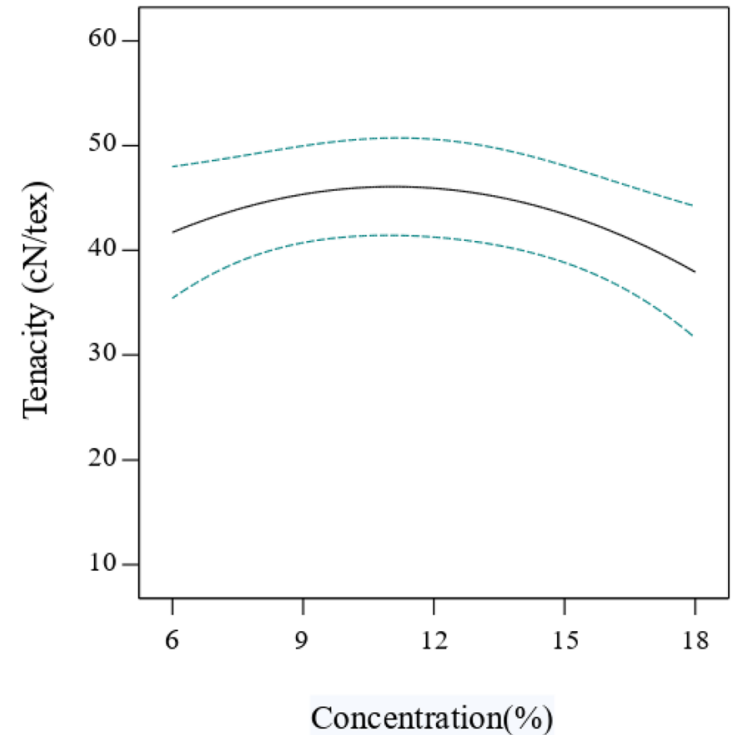

(a)

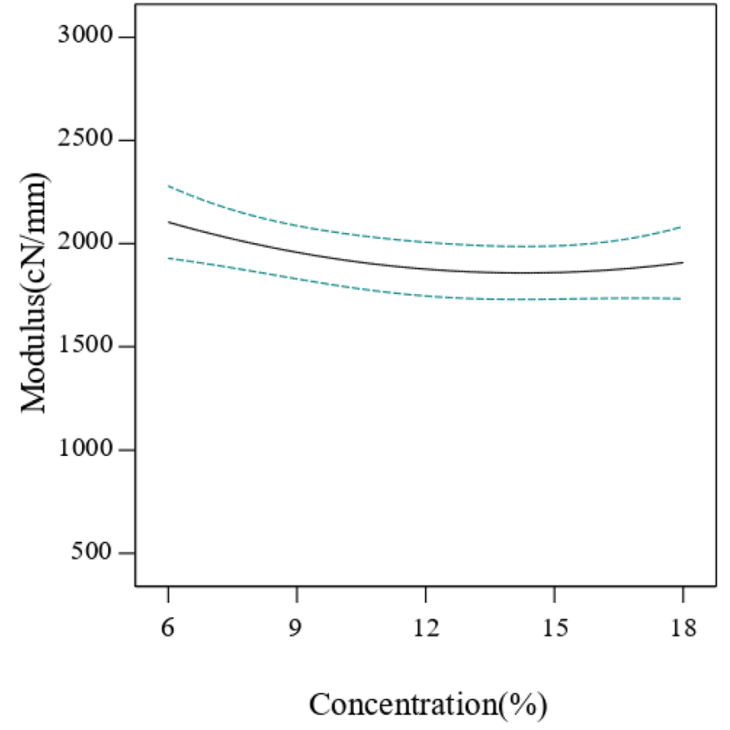

(b)

Fig. 9 Independent variables effect on the responses a Concentration versus Tenacity b Concentration versus Modulus

Fig. 11. The figure shows the breaking force, elongation, tenacity, work done, and modulus were all affected by the interaction of plant age, concentration, and soaking time parameters. In terms of plant age and soaking time, the mechanical properties (breaking force, elongation, tenacity, and work done) were maximized near 2.0 years, 2.0 days plant age, and soaking duration respectively. These mechanical properties reach their lowest point near to 1 year and 3 years, except for modulus. The modulus had its highest value below 2 years, 2.5 days, and the lowest value near to 3 years, 3 days plant age, and soaking duration respectively. Except for modulus, the lowest values were near 1 year and 18\% plant age and concentration respectively. The modulus was raised by reducing the plant age to approximately 1 year and the concentration to $6 \%$. The lowest modulus occurred at 3 years and below $9 \%$ plant age and 


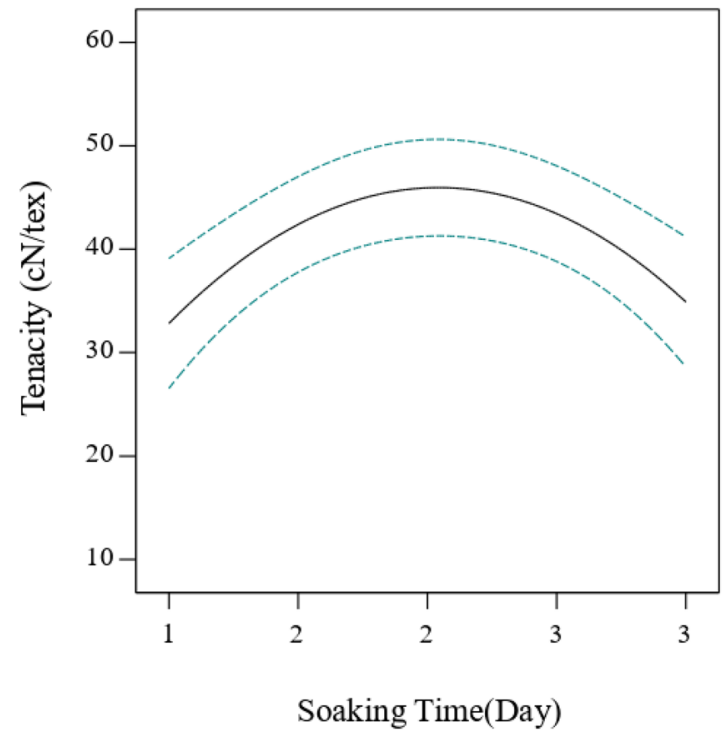

(a)

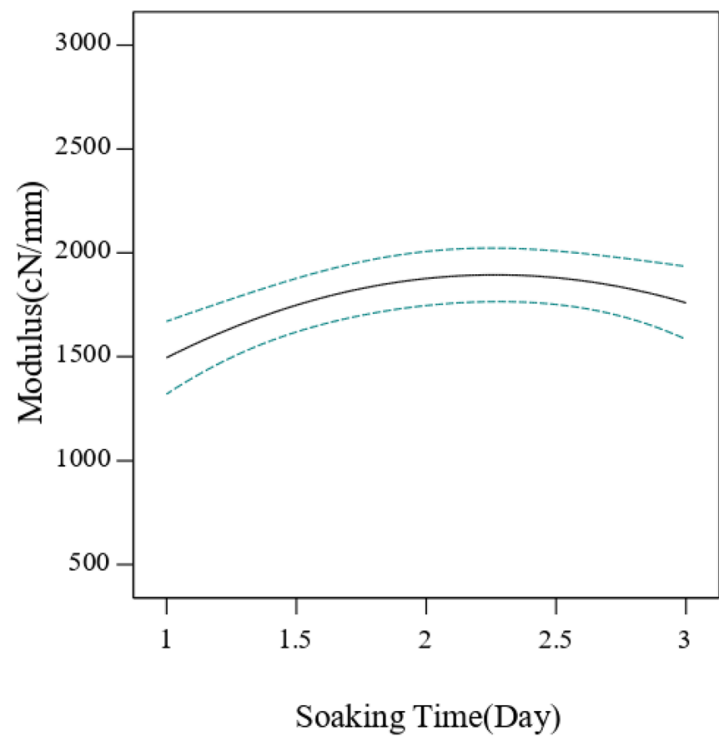

(b)

Fig. 10 independent variables effect on the responses a Soaking time versus Tenacity b Soaking time versus Modulus

concentration respectively. The interaction of soaking duration and concentration also affects the mechanical properties of highland bamboo. As seen in Fig. 5, the highest values occurred at around 2 days, $12 \%$, soaking duration, and concentration respectively, the lowest values were at the lower and upper limits of the variables. The modulus, on the other hand, differed from the other mechanical properties because the maximum values were attained near to $6 \%, 2$ days, and the lowest value was near to 14\%, 1-day concentration, and soaking time respectively.

\subsection{Model fitting and ANOVA analysis}

As shown in Table 9, the p-values were used to determine the significant interaction between factors and responses. Values of $P \leq 0.05$ were considered to be significant. Breaking force Model F-value of 7.80 implies the model is significant. In other words, there is only a $0.65 \%$ chance that an F-value this large could occur due to noise. In this case, the quadratic terms of plant age, soaking time, and concentration were the only significant model terms $(P \leq 0.0256)$. An F-value of elongation 6.93 has a $0.91 \%$ chance of occurring due to noise. The only significant model terms in the case of elongation $(P \leq 0.0496)$ were the interaction of plant age and soaking time, quadratic values of plant age, soaking time, and concentration. The tenacity model's F-value of 7.85 indicates that it was significant as this value has a $0.64 \%$ chance of occurring due to noise. The quadratic values of plant age, soaking duration, and concentration were the only model terms that were meaningful in the case of tenacity $(P \leq 0.0259)$. The Model F-value of work done, 21.00 , indicates that the model is significant as an F-value of this magnitude has a $0.03 \%$ chance of occurring due to noise. The $p$-values of the significant interactions between the factors and work done were used to assess their significance and the only significant model factors $(P \leq 0.0308)$ were concentration, the interaction between plant age and concentration, quadratic values of plant age, soaking time, and concentration. The F-value of 12.75 for the modulus model indicates that the model is significant. Due to noise, this F-value has a $0.14 \%$ probability of occurring. The only significant model factors of modulus $(P \leq 0.0189)$ were plant age, soaking time, plant age and concentration interaction, plant age and soaking time interaction, quadratic values of plant age, and soaking time.

$Y_{b}=780.76-163.54 A^{2}-103.64 B^{2}-205.33 C^{2}$

$Y_{e}=2.04-0.2850 A C-0.2775 A^{2}-0.3825 B^{2}-0.6375 C^{2}$

$$
Y_{t}=45.93-9.62 A^{2}-6.11 B^{2}-12.08 C^{2}
$$

$Y_{w}=508.22-49.67 B+86.14 A B-155.95 A^{2}-111.75 B^{2}-247.57 C^{2}$ 
Breaking Force

326.1

ए780.8

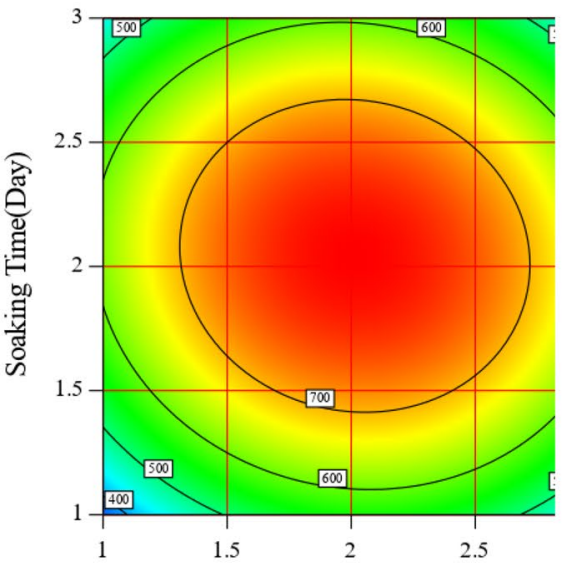

Age(Year)

Work done

54.21

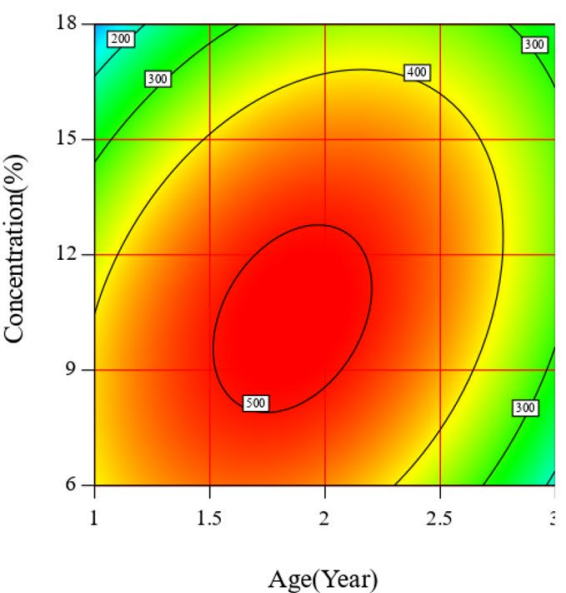

Elongation

$0.66 \square 2.04$

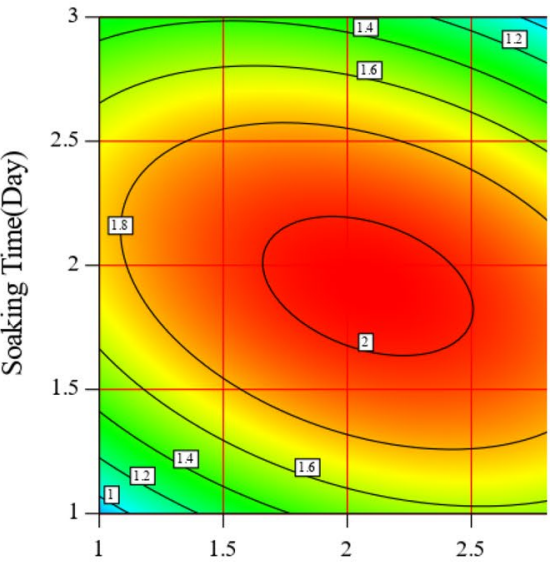

Age(Year)
Tenacity

19.18

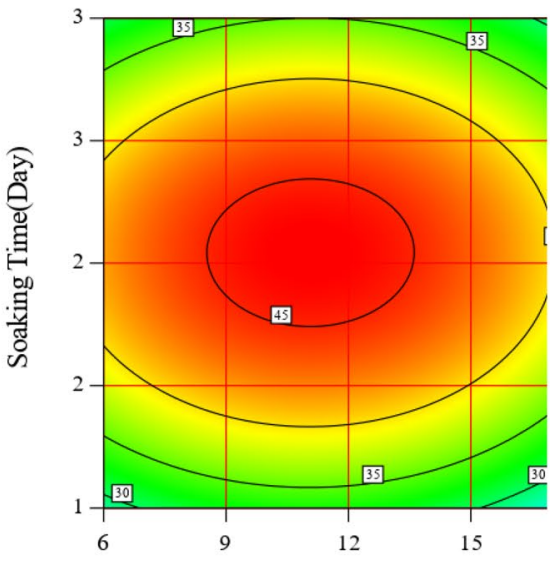

Concentration $(\%)$

Modulus

911.7

2463
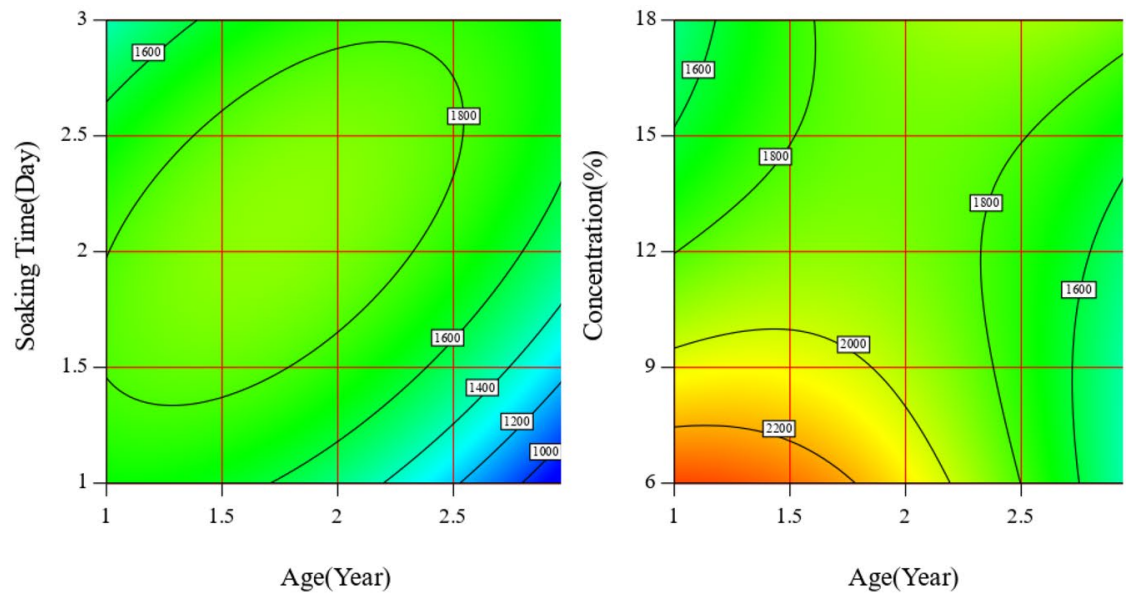

Fig. $112 \mathrm{D}$ plots of concentration versus plant age, soaking time versus plant age, and concentration versus soaking time on tested mechanical properties

$\boldsymbol{Y}_{\boldsymbol{m}}=1876.18-157.1 \boldsymbol{A}+336.49 A B+274.71 A C-236.76 \boldsymbol{A}^{2}-249.40 \boldsymbol{C}^{2}$

where $\mathrm{A}, \mathrm{B}$, and $\mathrm{C}$ represent fiber Age (year), $\mathrm{NaOH}$ concentration ( $w t \%)$, and soaking duration (day), respectively.

$Y_{b}, Y_{e}, Y_{t}, Y_{w}$, and $Y_{m}$ are breaking force, Elongation, Tenacity, Work done, and Modulus in terms of significant terms model equation respectively generated by RSM.

The quadratic model was used to fit the response value and detect which independent variables from Eq. 6 to Eq. 10 were affected for each of the responses through Analysis of Variance (ANOVA). Table 10 shows that quadratic coefficients of the soaking duration except modulus have the highest values among the linear, quadratic, and interaction coefficients of significant independent variables. This shows that the quadratic values of the soaking duration have a significant effect on breaking force $(P \leq 0.0008)$, elongation $(P \leq 0.001)$, tenacity $(P \leq 0.0008)$, and work done $(P \leq 0.0001)$. The coefficient of $A B$ has the highest value among the coefficients of the significant independent variables in the equation of modulus, indicating that the interaction of plant age and alkali concentration $(P \leq 0.0009)$ has the most positive effect on the model equation. 
Table 9 Analysis of variance for response surface quadratic model of alkali-treated Y.alpina bamboo fiber

\begin{tabular}{|c|c|c|c|c|c|c|c|c|c|c|}
\hline \multirow[t]{2}{*}{ Source } & \multicolumn{2}{|c|}{ Breaking force } & \multicolumn{2}{|c|}{ Elongation } & \multicolumn{2}{|l|}{ Tenacity } & \multicolumn{2}{|c|}{ Work done } & \multicolumn{2}{|c|}{ Modulus } \\
\hline & F-value & $p$-value & F-value & $p$-value & F-value & $p$-value & F-value & $p$-value & F-value & $p$-value \\
\hline Model & 7.8 & $0.0065^{*}$ & 6.93 & $0.0091^{*}$ & 7.85 & $0.0064^{*}$ & 21 & $0.0003^{*}$ & 12.75 & $0.0014^{*}$ \\
\hline$A$ & 0.047 & 0.835 & 0.0702 & 0.7987 & 0.0492 & 0.8308 & 1.21 & 0.3072 & 13.01 & 0.0087 \\
\hline B & 1.49 & 0.2612 & 3.12 & 0.1208 & 1.47 & 0.2643 & 7.27 & 0.0308 & 5.08 & 0.0589 \\
\hline$C$ & 0.45 & 0.5237 & 0.9432 & 0.3638 & 0.4447 & 0.5262 & 0.4908 & 0.5062 & 9.23 & 0.0189 \\
\hline$A B$ & 2.43 & 0.1634 & 1.56 & 0.2519 & 2.41 & 0.1643 & 10.93 & 0.013 & 29.84 & 0.0009 \\
\hline$A C$ & 0.32 & 0.5894 & 5.63 & 0.0494 & 0.3217 & 0.5883 & 1.17 & 0.3148 & 19.89 & 0.0029 \\
\hline $\mathrm{BC}$ & $1 \mathrm{E}-04$ & 0.9921 & 0.5612 & 0.4782 & 0.0005 & 0.9826 & 0.4008 & 0.5468 & 0.191 & 0.6756 \\
\hline$A^{2}$ & 19.87 & 0.0029 & 5.62 & 0.0496 & 19.98 & 0.0029 & 37.71 & 0.0005 & 15.55 & 0.0056 \\
\hline$B^{2}$ & 7.98 & 0.0256 & 10.67 & 0.0137 & 8.07 & 0.025 & 19.36 & 0.0032 & 4.66 & 0.0678 \\
\hline$C^{2}$ & 31.33 & 0.0008 & 29.64 & 0.001 & 31.51 & 0.0008 & 95.03 & $<0.0001$ & 17.25 & 0.0043 \\
\hline Lack of Fit & 1.322 & $0.397^{* *}$ & 0.1347 & $0.404^{* *}$ & 0.4551 & $0.135^{* *}$ & 0.6336 & $0.091^{* *}$ & 0.354 & $0.1063^{* *}$ \\
\hline
\end{tabular}

A age(Year) B Concentration (\%) C Soaking Time(Day) * Significant **Not Significant

Table 10 Coefficients of responses: $\boldsymbol{Y}_{\boldsymbol{b}}, \boldsymbol{Y}_{e}, \boldsymbol{Y}_{t}, \boldsymbol{Y}_{w}$, and $\boldsymbol{Y}_{m}$ are the breaking force, Elongation, Tenacity, Work done, and Modulus, respectively

\begin{tabular}{|c|c|c|c|c|c|}
\hline \multirow[t]{2}{*}{ Coefficients } & \multicolumn{5}{|c|}{ Mechanical properties (Responses) } \\
\hline & $Y_{b}$ & $\mathrm{Y}_{\mathrm{e}}$ & $Y_{t}$ & $Y_{w}$ & $\mathrm{Y}_{\mathrm{m}}$ \\
\hline$\beta_{0}$ & 780.76 & 2.04 & 45.93 & 508.22 & 1876.18 \\
\hline$\beta_{1}$ & 5.75 & 0.0225 & 0.3463 & -20.29 & -157.10 \\
\hline$\beta_{2}$ & -32.53 & -0.15 & -1.89 & -49.67 & -98.15 \\
\hline$\beta_{3}$ & 17.86 & -0.0825 & 1.04 & 12.91 & 132.35 \\
\hline$\beta_{12}$ & 58.61 & 0.15 & 3.43 & 86.14 & 336.49 \\
\hline$\beta_{13}$ & -21.28 & -0.2850 & -1.25 & -28.22 & 274.71 \\
\hline$\beta_{23}$ & 0.3875 & 0.09 & 0.05 & -16.49 & 26.89 \\
\hline$\beta_{11}$ & -163.54 & -0.2775 & -9.62 & -155.95 & -236.76 \\
\hline$\beta_{22}$ & -103.64 & -0.3825 & -6.11 & -111.75 & 129.56 \\
\hline$\beta_{33}$ & -205.33 & -0.6375 & -12.08 & -247.57 & -249.40 \\
\hline$\beta_{123}$ & 0.000 & 0.00 & 0.00 & 0.00 & 0.00 \\
\hline
\end{tabular}

\section{Optimization and confirmation test}

The Design-Expert software's optimization tool was utilized to determine the best parameters for the alkalitreated Y.alpina bamboo single fibers. As shown in Table 11, the parameters that affect significantly the responses (breaking force, elongation tenacity, work done, and modulus) on the range between 326.1 and $780.8 \mathrm{cN}$, 0.665 to $2.04 \%, 19.18-45.93 \mathrm{cNtex}^{-1}, 54.21-508.2 \mathrm{cNmm}$, and $911.7-2463 \mathrm{cNtex}^{-1}$ was set as predicted values of breaking force, elongation, tenacity, work done, and modulus respectively with the three factors balanced within the ranges that were measured and Box-behnken design (BBD) analysis error (\%) values of experimental with predicted values of responses (Table 12). The conditions to optimize mechanical properties were a plant age of 1.8 years, a $\mathrm{NaOH}$ concentration of $10 \%$, and a soaking duration of 2.0 days. The optimal values at these variables of breaking force, elongation, tenacity, work done, and modulus is $777.8 \mathrm{cN}, 2.0 \%, 45.7 \mathrm{cNtex}^{-1}, 516.3 \mathrm{cNmm}$, and $1969 \mathrm{cNtex}^{-1}$, respectively, according to the BBD results.

To validate the model, a confirmation of five experiments was performed. Samples were prepared by using the optimal variables obtained by BBD (1.8 years age, $10 \% \mathrm{NaOH}$ concentration, and 2 days soaking days), and mean values of the experimental results (breaking force, Elongation, Tenacity, Work done, and Modulus) were, $779.8 \mathrm{cN}, 3.0 \%, 48.01 \mathrm{cNtex}^{-1}, 511.22 \mathrm{cNmm}$, and $2001.12 \mathrm{cNtex}^{-1}$ respectively. Results demonstrated that the percentage error between the measured and predicted value was well within the value of $5 \%$. This demonstrated that the model's validity was verified and the existence of the optimal point was confirmed by the good agreement between predicted and experimental results.

\section{Conclusions}

This study was conducted to generate information about the mechanical (Breaking force, Elongation, Tenacity, Work done, and Modulus), thermal and chemical properties of the alkali-treated Y.alpina Ethiopia indigenous bamboo species single fiber. The response surface methodology Box-Benhken design was used to evaluate the effect of three independent variables (plant age, soaking duration, and $\mathrm{NaOH}$ concentration) on the mechanical properties of Y.alpina bamboo single fibers. Using this software optimization and showing linear, quadratic, and interaction effects of independent variables on the mechanical properties was carried out. Optimal 
Table 11 Predicted values of responses (breaking force, elongation tenacity, work done, and modulus)

\begin{tabular}{lllllllll}
\hline Run & $\begin{array}{l}\text { A } \\
\text { Year }\end{array}$ & $\begin{array}{l}\text { B } \\
\%\end{array}$ & $\begin{array}{l}\text { C } \\
\text { Day }\end{array}$ & $\begin{array}{l}\text { Breaking Force } \\
\text { cN }\end{array}$ & $\begin{array}{l}\text { Elongation } \\
\%\end{array}$ & $\begin{array}{l}\text { Tenacity } \\
\text { cNtex }\end{array}$ & $\begin{array}{l}\text { Work done } \\
\text { cNmm }\end{array}$ & $\begin{array}{l}\text { Modulus } \\
\text { cNtex }^{-1}\end{array}$ \\
\hline 1 & 2 & 12 & 2 & 780.8 & 2.0 & 45.9 & 508.2 & 1876.2 \\
2 & 1 & 6 & 2 & 599.0 & 1.7 & 35.2 & 396.6 & 2360.7 \\
3 & 2 & 6 & 1 & 486.9 & 1.3 & 28.6 & 169.2 & 1749.0 \\
4 & 1 & 12 & 1 & 367.0 & 0.9 & 21.6 & 83.9 & 1689.5 \\
5 & 3 & 12 & 1 & 421.1 & 1.5 & 24.8 & 99.7 & 825.9 \\
6 & 1 & 18 & 2 & 416.7 & 1.1 & 24.5 & 125.0 & 1491.5 \\
7 & 3 & 18 & 2 & 545.4 & 1.4 & 32.1 & 256.7 & 1850.2 \\
8 & 3 & 6 & 2 & 493.3 & 1.4 & 29.0 & 183.8 & 1373.5 \\
9 & 2 & 6 & 3 & 521.8 & 1.0 & 30.6 & 228.0 & 1959.9 \\
10 & 1 & 12 & 3 & 445.3 & 1.3 & 26.2 & 166.1 & 1404.8 \\
11 & 2 & 18 & 1 & 421.0 & 0.9 & 24.8 & 102.8 & 1499.0 \\
12 & 2 & 18 & 3 & 457.5 & 0.9 & 26.9 & 95.6 & 1817.4 \\
13 & 3 & 12 & 3 & 414.2 & 0.8 & 24.4 & 69.1 & 1640.0 \\
\hline
\end{tabular}

Table 12 Box-behnken design (BBD) analysis standard error (\%) values of expermental with predicted values of responses

\begin{tabular}{|c|c|c|c|c|c|}
\hline Run & Breaking force & Elongation & Tenacity & Work done & Modulus \\
\hline 1 & 0.0 & 0.0 & 0.0 & 0.0 & 0.0 \\
\hline 2 & -0.6 & 0.7 & -0.6 & 0.7 & 1.7 \\
\hline 3 & -0.7 & -0.2 & -0.7 & -1.1 & -2.6 \\
\hline 4 & 1.4 & -0.5 & 1.4 & 0.5 & 0.9 \\
\hline 5 & 1.9 & 2.4 & 1.9 & 2.6 & 1.4 \\
\hline 6 & 1.2 & 2.2 & 1.2 & 1.4 & -1.2 \\
\hline 7 & 0.6 & -0.7 & 0.6 & -0.7 & -1.7 \\
\hline 8 & -1.2 & -2.1 & -1.2 & -1.4 & 1.2 \\
\hline 9 & 2.5 & 1.7 & 2.5 & 1.9 & -0.3 \\
\hline 10 & -1.9 & -2.4 & -1.9 & -2.6 & -1.4 \\
\hline 11 & -2.5 & -1.7 & -2.5 & -1.9 & 0.3 \\
\hline 12 & 0.7 & 0.2 & 0.7 & 1.1 & 2.6 \\
\hline 13 & -1.4 & 0.5 & -1.4 & -0.5 & -0.9 \\
\hline
\end{tabular}

mechanical properties were attained at optimal points of a plant age 1.8 years, $\mathrm{NaOH}$ content of $10 \%$ (wt/vol $\%$.), and soaking duration of 2.0 days. At these points (age 1.8 years and soaking duration 2.0 days) the thermal, morphological, and functional group identification was explored for the corresponding alkali concentration of 6,12 , and $18 \%$. Increasing the alkali concentration promotes weight reduction by improving the removal of lignin and hemicellulose components. Thermal and mechanical properties, on the other hand, varied up to a point. Except for modulus, mechanical characteristics improved when concentration and age were increased to $12 \%$ and 2 years age respectively and then dropped. The $12 \% \mathrm{NaOH}$ concentration exhibits the best thermal stability properties among the $6-18 \% \mathrm{NaOH}$ treated Y.alphina bamboo fibers. The surface appearance and microfibril aggregates in the cell wall were altered by alkali treatment.

Acknowledgements The Ethiopian Textile and Fashion Technology Institute (EiTEX) financed this research as part of a Ph.D. dissertation on sustainable energy engineering at the Bahir Dar institute of technology (BIT) Energy center, Bahir Dar University, Bahir Dar. Assistance for the collection of inquires about materials during the experiments from Amhara agricultural research institutes (ARARI) is gratefully accredited.

Funding The authors have not disclosed any funding.

\section{Declarations}

Conflict of interest The author declare that they have no conflict of interest.

Open Access This article is licensed under a Creative Commons Attribution 4.0 International License, which permits use, sharing, adaptation, distribution and reproduction in any medium or format, as long as you give appropriate credit to the original author(s) and the source, provide a link to the Creative Commons licence, and indicate if changes were made. The images or other third party material in this article are included in the article's Creative Commons licence, unless indicated otherwise in a credit line to the material. If material is not included in the article's Creative Commons licence and your intended use is not permitted by statutory regulation or exceeds the permitted use, you will need to obtain permission directly from the copyright holder. To view a copy of this licence, visit http://creativecommons. org/licenses/by/4.0/.

\section{References}

1. Pitchayya Pillai G, Manimaran P, Vignesh V (2020) Physico-chemical and mechanical properties of alkali-treated red banana peduncle fiber. J. Nat. Fibers 18(12):2102-2111 
2. Du L, Li Y, Lee S, Wu Q (2014) Water absorption properties of heat-treated bamboo fiber and high density polyethylene composites. BioResources 9(1):1189-1200. https://doi.org/10.15376/ biores.9.1.1189-1200

3. Buson RF, Melo LFL, Oliveira MN, Rangel GAVP, Deus EP (2018) Physical and mechanical characterization of surface treated bamboo fibers. Sci Technol Mater. https://doi.org/10.1016/j. stmat.2018.03.002

4. Liu L, Wang Q, Cheng L, Qian J, Yu J (2011) Modification of natural bamboo fibers for textile applications. Fibers Polym 12(1):95103. https://doi.org/10.1007/s12221-011-0095-3

5. Sisika (2011) "Bamboo fabric: a study of using thick bamboo fiber for producing and developing thai textiles," J Soc Sci, 7(3):462-465, 2011, doi: https://doi.org/10.3844/jssp.2011.462. 465.

6. Scurlock JMO, Dayton DC, Hames B (2000) Bamboo: an overlooked biomass resource? Biomass Bioenerg 19(4):229-244. https://doi.org/10.1016/S0961-9534(00)00038-6

7. Kantarelis E, Liu J, Yang W, Blasiak W (2010) Sustainable valorization of bamboo via high-temperature steam pyrolysis for energy production and added value materials. Energy Fuels 24(11):6142-6150. https://doi.org/10.1021/ef100875g

8. Li MF, Fan YM, Xu F, Sun RC, Zhang XL (2010) Cold sodium hydroxide/urea based pretreatment of bamboo for bioethanol production: Characterization of the cellulose rich fraction. Ind Crops Prod 32(3):551-559. https://doi.org/10.1016/j.indcrop. 2010.07.004

9. Sreadha AR, Pany C (2020) Review on fabrication of bamboo composite materials reinforced concrete. J Sci Tech 5(3):258-279

10. Atanda J (2015) Environmental impacts of bamboo as a substitute constructional material in Nigeria. Case Stud Constr Mater 3:33-39. https://doi.org/10.1016/j.cscm.2015.06.002

11. Prem Kumar V, Vasugi V (2020) Bamboo materials in cement, geopolymer and reinforced concrete as sustainable solutions for better tomorrow. IOP Conf Ser Earth Environ Sci. https://doi. org/10.1088/1755-1315/573/1/012036

12. Ghavami K (2005) Bamboo as reinforcement in structural concrete elements. Cem Concr Compos 27(6):637-649. https://doi. org/10.1016/j.cemconcomp.2004.06.002

13. Lima HC, Willrich FL, Barbosa NP, Rosa MA, Cunha BS (2008) Durability analysis of bamboo as concrete reinforcement. Mater Struct Constr 41(5):981-989. https://doi.org/10.1617/ s11527-007-9299-9

14. Yang Z, Xu S, Ma X, Wang S (2008) Characterization and acetylation behavior of bamboo pulp. Wood Sci Technol 42(8):621-632. https://doi.org/10.1007/s00226-008-0194-5

15. Vena PF, Brienzo M, García-Aparicio MDP, Görgens JF, Rypstra T (2013) Hemicelluloses extraction from giant bamboo (Bambusa balcooa Roxburgh) prior to kraft or soda-AQ pulping and its effect on pulp physical properties. Holzforschung 67(8):863870. https://doi.org/10.1515/hf-2012-0197

16. Aklilu EG (2020) Optimization and modeling of ethanol-alkali pulping process of bamboo (Yushania alpina) by response surface methodology. Wood Sci Technol 54(5):1319-1347. https:// doi.org/10.1007/s00226-020-01188-z

17. Adhikari RC, Wood DH, Sudak L (2015) Low-cost bamboo lattice towers for small wind turbines. Energy Sustain Dev 28:21-28. https://doi.org/10.1016/j.esd.2015.06.006

18. Rassiah K, Ahmad MMHM (2013) A review on mechanical properties of bamboo fiber reinforced polymer composite. Aust J Basic Appl Sci. https://doi.org/10.15376/biores.11.4.shah

19. Kamruzzaman M, Saha SK, Bose AK, Islam MN (2008) Effects of age and height on physical and mechanical properties of bamboo. J Trop For Sci 20(3):211-217
20. F. R. Falayi, B. O. Soyoye, and T. O. Tehinse, "The influence of age and location on selected physical and mechanical properties of bamboo (Phyllostachys pubesces)," Int. J. Res. Agric. For., vol. 1, no. 1, pp. 44-54, 2014, [Online]. Available: www.ijraf.org.

21. Chou TN, Bin Young W (2018) Strength of untreated and alkalitreated bamboo fibers and reinforcing effects for short fiber composites. J. Aeronaut. Astronaut. Aviat. 50(3):237-246

22. Tong FS et al (2018) Pengaruh rawatan alkali terhadap sifatsifat fizikal-kimia serat buluh Malaysia: Satu kajian awal. Malaysian J Anal Sci 22(1):143-150. https://doi.org/10.17576/ mjas-2018-2201-18

23. Chen $\mathrm{H}$ et al (2017) Effect of alkali treatment on microstructure and mechanical properties of individual bamboo fibers. Cellulose 24(1):333-347. https://doi.org/10.1007/s10570-016-1116-6

24. Hassan MZ et al (2020) Mercerization optimization of bamboo (Bambusa vulgaris) fiber-reinforced epoxy composite structures using a Box-Behnken design. Polymers (Basel) 12(6):1-19. https://doi.org/10.3390/POLYM12061367

25. Júnior $A E C$, Barreto $A C H$, Rosa DS, Maia FJN, Lomonaco D, Mazzetto SE (2015) Thermal and mechanical properties of biocomposites based on a cashew nut shell liquid matrix reinforced with bamboo fibers. J Compos Mater 49(18):2203-2215. https:// doi.org/10.1177/0021998314545182

26. Ren D, Yu Z, Li W, Wang H, Yu Y (2014) The effect of ages on the tensile mechanical properties of elementary fibers extracted from two sympodial bamboo species. Ind Crops Prod. https:// doi.org/10.1016/j.indcrop.2014.08.014

27. Zhai R, Ma J, Hu Z, Hou J (2018) The effects of $\mathrm{NaOH}$-urea aqueous solution on the strength and softness properties of bamboo ligno-cellulosic fibers. Bioresources 13(1):1088-1106

28. Kim H, Okubo K, Fujii T, Takemura K (2013) Influence of fiber extraction and surface modification on mechanical properties of green composites with bamboo fiber. J Adhes Sci Technol 27(12):1348-1358. https://doi.org/10.1080/01694243.2012. 697363

29. Phong NT, Fujii T, Chuong B, Okubo K (2011) Study on How to Effectively Extract Bamboo Fibers from Raw Bamboo and Wastewater Treatment. J Mater Sci Res 1(1):144-155. https://doi.org/ 10.5539/jmsr.v1n1p144

30. Nugroho N, Ando N (2001) Development of structural composite products made from bamboo II: fundamental properties of laminated bamboo lumber. J Wood Sci 47(3):237-242. https:// doi.org/10.1007/BF01171228

31. Das M, Chakraborty D (2006) Influence of alkali treatment on the fine structure and morphology of bamboo fibers. J Appl Polym Sci 102(5):5050-5056. https://doi.org/10.1002/app.25105

32. Hidayati S, Suroso E, Satyajaya W, Iryani DA (2019) Chemistry and Structure Characterization of Bamboo Pulp with Formacell Pulping. IOP Conf Ser Mater Sci Eng. https://doi.org/10.1088/ 1757-899X/532/1/012024

33. Shao Z, Wang $F$ (2018) The fracture mechanics of plant materials. Springer, Singapore

34. Singh B, Dessalegn $Y$ (2021) Effect analysis of extraction processes of bamboo fiber. NVEO-NATURAL VOLATILES \& ESSENTIAL OILS J 8(5):4226-4246

35. Feleke $S$ (2013) Site factor on nutritional content of Arundinaria alpina and Oxytenanthera abyssinica bamboo shoots in Ethiopia. J Hortic For 5(8):115-121. https://doi.org/10.5897/JHF2013. 0303

36. Mekonnen Z, Worku A, Yohannes T, Alebachew M, Teketay D, Kassa $\mathrm{H}$ (2014) Bamboo resources in Ethiopia: Their value chain and contribution to livelihoods. Ethnobot Res Appl 12(November):511-524. https://doi.org/10.17348/era.12.0.511-524

37. Chin SC, Tee KF, Tong FS, Ong HR, Gimbun J (2019) Thermal and mechanical properties of bamboo fiber reinforced composites. 
Mater Today Commun. https://doi.org/10.1016/j.mtcomm.2019. 100876

38. Chen $\mathrm{H}$ et al (2018) Effect of alkali treatment on wettability and thermal stability of individual bamboo fibers. J Wood Sci 64(4):398-405. https://doi.org/10.1007/s10086-018-1713-0

39. Worku AK, Ayele DW, Habtu NG, Teshager MA, Workineh ZG (2021) Recent progress in MnO2-based oxygen electrocatalysts for rechargeable zinc-air batteries. Mater Today Sustain 13:100072. https://doi.org/10.1016/j.mtsust.2021.100072

40. Dorez G, Ferry L, Sonnier R, Taguet A, Lopez-Cuesta JM (2014) Effect of cellulose, hemicellulose and lignin contents on pyrolysis and combustion of natural fibers. J Anal Appl Pyrolysis 107:323-331. https://doi.org/10.1016/j.jaap.2014.03.017

41. Wang S, Ru B, Lin H, Luo Z (2013) Degradation mechanism of monosaccharides and xylan under pyrolytic conditions with theoretic modeling on the energy profiles. Bioresour Technol 143:378-383. https://doi.org/10.1016/j.biortech.2013.06.026

42. Mosisa S, Batu T (2021) Investigation of mechanical properties of bamboo/sisal fiber reinforced hybrid composite materials. Mater Sci Eng Int J 5(2):24-31. https://doi.org/10.15406/mseij. 2021.05.00152

43. Thammapornram C, Kongsong W, Buranakarn V (2018) Effecting factors of the mechanical properties of Thai Dendrocalamus gigantues bamboo. Int J Civ Eng Technol 9(13):1457-1467

44. Ming CYT, Jye WK, Ahmad HAI (2017) “Mechanical properties of bamboo and bamboo composites: A Review," J Adv Res Mater Sci, 35(January):7-26, 2017, [Online]. Available: https://www. researchgate.net/publication/332800151

45. Subash S, SJRB, ERDJ (2017) "A Review on Extraction of Bamboo Fibres and Its Properties 1 1,2,3," 2017.

46. Huang YH, Fei BH, Yu Y, Zhao RJ (2012) Plant age effect on mechanical properties of moso bamboo (Phyllostachys heterocycla var. pubescens). Wood Fiber Sci 44(2):196-201

47. Nemeth MA (2003) Response surface methodology: process and product optimization using designed experiments, 2nd edition. J Qual Technol 35(4):428-429. https://doi.org/10.1080/00224 065.2003 .11980243

48. Wu L, Yick KL, Ng SP, Yip J (2012) Application of the Box-Behnken design to the optimization of process parameters in foam cup molding. Expert Syst Appl 39(9):8059-8065. https://doi.org/10. 1016/j.eswa.2012.01.137

49. Sultana N, Hossain SMZ, Alam MS, Hashish MMA, Islam MS (2020) An experimental investigation and modeling approach of response surface methodology coupled with crow search algorithm for optimizing the properties of jute fiber reinforced concrete. Constr Build Mater 243:118216. https://doi.org/10. 1016/j.conbuildmat.2020.118216

50. Qiu P et al (2014) Application of Box-Behnken design with response surface methodology for modeling and optimizing ultrasonic oxidation of arsenite with $\mathrm{H}$ 2O2. Cent Eur J Chem 12(2):164-172. https://doi.org/10.2478/s11532-013-0360-y

51. Hestiawan H (2016) Jamasri, and Kusmono, "A Preliminary Study: Influence of Alkali Treatment on Physical and Mechanical Properties of Agel Leaf Fiber (Corypha gebanga)". Appl Mech Mater 842(June):61-66. https://doi.org/10.4028/www.scientific.net/ amm.842.61

52. Ridzuan MJM, Majid MSA, Afendi M, Azduwin K, Kanafiah SNA, Dan-mallam Y (2015) The Effects of the Alkaline Treatment's Soaking Exposure on the Tensile Strength of Napier Fibre. Procedia Manuf 2(December):353-358. https://doi.org/10.1016/j. promfg.2015.07.062

53. Zhang SY, Fei BH, Yu Y, Cheng HT, Wang CG (2013) Effect of the amount of lignin on tensile properties of single wood fibers. For Sci Pract 15(1):56-60. https://doi.org/10.1007/ s11632-013-0106-0
54. Martijanti M, Juwono AL, Sutarno S (2020) Investigation of characteristics of bamboo fiber for composite structures. IOP Conf Ser Mater Sci Eng. https://doi.org/10.1088/1757-899X/850/1/ 012028

55. Li Z, Jiang Z, Fei B, Yu Y, Cai Z (2012) Effective of microwave-KOH pretreatment on enzymatic hydrolysis of bamboo. J Sustain Bioenergy Syst 02(04):104-107. https://doi.org/10.4236/jsbs.2012. 24015

56. Tolessa A, Woldeyes B, Feleke S (2017) Chemical composition of lowland Bamboo (Oxytenanthera abyssinica) grown around asossa town, Ethiopia. World Sci News 74:141-151

57. Mahelete T, Chandravanshi BS, Feleke S, Mesfin R (2020) Chemical composition of yushania alpina (K. Schum.) WC Lin (1974) (Highland bamboo) grown in Ethiopia. World News Nat. Sci. 32:1-9

58. Mahanim SMA, Wan Asma I, Rafidah J, Puad E, Shaharuddin H (2011) Production of activated carbon from industrial bamboo wastes. J Trop For Sci 23(4):417-424

59. Purbasari A, Samadhi TW, Bindar Y (2016) Thermal and Ash characterization of indonesian bamboo and its potential for solid fuel and waste valorization. Int J Renew Energy Dev 5(2):95-100. https://doi.org/10.14710/ijred.5.2.95-100

60. Park SH, Jang JH, Wistara NJ, Febrianto F, Lee M (2019) Fuel properties of indonesian bamboo carbonized at different temperatures. BioResources 14(2):4224-4235. https://doi.org/10.15376/ biores.14.2.4224-4235

61. Shih YF (2007) Mechanical and thermal properties of waste water bamboo husk fiber reinforced epoxy composites. Mater Sci Eng A 445-446:289-295. https://doi.org/10.1016/j.msea. 2006.09.032

62. Lu T, Jiang M, Jiang Z, Hui D, Wang Z, Zhou Z (2013) Effect of surface modification of bamboo cellulose fibers on mechanical properties of cellulose/epoxy composites. Compos Part B Eng 51:28-34. https://doi.org/10.1016/j.compositesb.2013.02.031

63. Zhang K, Wang F, Liang W, Wang Z, Duan Z, Yang B (2018) Thermal and mechanical properties of bamboo fiber reinforced epoxy composites. Polymers Basel. https://doi.org/10.3390/ polym 10060608

64. Prithivirajan R et al (2020) Characterization of musa paradisiaca L. cellulosic natural fibers from agro-discarded blossom petal waste. J Nat Fibers 17(11):1640-1653. https://doi.org/10.1080/ 15440478.2019 .1588826

65. Xu G, Wang L, Liu J, Wu J (2013) Applied surface science FTIR and XPS analysis of the changes in bamboo chemical structure decayed by white-rot and brown-rot fungi. Appl Surf Sci 280:799-805. https://doi.org/10.1016/j.apsusc.2013.05.065

66. Li X, Wei Y, Xu J, Xu N, He Y (2018) Biotechnology for Biofuels Quantitative visualization of lignocellulose components in transverse sections of moso bamboo based on FTIR macro - and micro - spectroscopy coupled with chemometrics. Biotechnol Biofuels. https://doi.org/10.1186/s13068-018-1251-4

67. M. Fan, D. Dai, and B. Huang, "Fourier Transform Infrared Spectroscopy for Natural Fibres," 2012, doi: 978-953-51-0594-7.

68. A. Y. Hanna B. Lemma, Zebene Kiflie, Sisay Feleke, "Chemical and Morphological Analysis of Enset (Ensete Ventricosum) Fiber, Leaf, and Pseudo stem," vol. 5, no. 2, pp. 139-151, 2016.

69. J. Coates, "Interpretation of Infrared Spectra, A Practical Approach," Encycl. Anal. Chem., pp. 1-23, 2006, doi: https://doi. org/10.1002/9780470027318.a5606.

70. Zhang X, Wang F, Keer LM (2015) Influence of surface modification on the microstructure and thermo-mechanical properties of bamboo fibers. Materials (Basel) 8(10):6597-6608. https://doi. org/10.3390/ma8105327

71. Zhong T, Oporto GS, Jaczynski J, Jiang C (2015) Nanofibrillated cellulose and copper nanoparticles embedded in polyvinyl 
alcohol films for antimicrobial applications. Biomed Res Int. https://doi.org/10.1155/2015/456834

72. Shravanabelagola Nagaraja Setty VK, Goud G, Peramanahalli Chikkegowda S, Mavinkere Rangappa S, Siengchin S (2020) Characterization of chemically treated limonia acidissima (wood apple) shell powder: physicochemical, thermal, and morphological properties. J Nat Fibers. https://doi.org/10.1080/ 15440478.2020.1853925

73. Salih AA, Zulkifli R, Azhari CH (2020) Tensile properties and microstructure of alkali treatment. Fibers $8(26): 1-10$

Publisher's Note Springer Nature remains neutral with regard to jurisdictional claims in published maps and institutional affiliations. 